$$
\text { rozhovor }
$$





\section{O bílých havranech a síle příběhu}

S básnířkou, spisovatelkou, překladatelkou, ilustrátorkou a literární badatelkou Luisou Novákovou jsme se potkali na Filozofické fakultě Masarykovy univerzity v Brně. Zde působí jako odborná asistentka na Ústavu české literatury a knihovnictví. U příležitosti vydání tematického čísla časopisu, jehož je také dlouholetou redaktorkou, jsme se jí vyptávali na její práci literární a vědeckou a snažili jsme se vyzvědět, čím to, že se jí to tak hezky všechno daří. A protože se již známe nějaký pátek, odložili jsme oficiální tón a zachováváme i v našem rozhovoru tykání.

Literatura pro děti a mládež stojí jakoby v ústraní, ve stínu literárněvědných bádání. Přitom četba a poslech literatury formují od útlého dětství vnimání, vidění, prožívání a chápání světa. Vedle hry, zpěvu a výtvarných činností dítěte přispívá slovesnost podstatnou měrou $k$ rozvoji jeho osobnosti. $V$ českém prostředí patříš $k$ významným badatelkám v oblasti literatury pro děti a mládež. Co vlivnilo tvé rozhodnutí věnovat se výzkumu v této oblasti?

Důvodů, proč jsem si jako hlavní oblast odborného zájmu vybrala literaturu pro děti a mládež, bylo víc. Přitom už dnes těžko dokážu říct, který byl ten první. Občas se mi zdá, jako by si spíš ona vybrala mě než naopak.

Zcela souhlasím, že dětská literatura je, nebo přinejmenším může být, pro vývoj osobnosti velmi důležitá. Máme-li možnost setkat se jako děti a během dospívání s kvalitními knížkami, co nás dokážou vtáhnout do svého světa, pravděpodobně v nás některé zůstanou zakořeněny na celý život, dokonce nás asi budou tu a tam celý život podvědomě ovlivňovat.

Můj vztah k dětské literatuře nepochybně formovala i rodina. Ačkoli literatura pro děti opravdu byla a do značné míry zůstává popelkou literární vědy, u nás doma, kde se maminka věnovala psaní dětských knížek a táta coby redaktor jejich vydávání (má k ní jako žák Františka Tenčíka ostatně blízko i teoreticky), byla doceňována vždycky. A byla odmalička součástí mého života nejen posluchačsky a čtenářsky. 
Jakými tématy se v oblasti literatury pro děti a mládež zabýváš? A čím tě tato témata přitahují?

Nejvíce pozornosti jsem zatím věnovala pohádce a od ní se posunula $\mathrm{k}$ fantasy, pohádce v mnohém velmi blízké. Na obou těchto žánrech mě přitahuje, jak svébytným a osobitým způsobem zrcadlí skutečný svět a vztahují se k němu: Na jedné straně jsou naší všednodennosti zdánlivě vzdálené - na druhé mají schopnost uchopit to nejzákladnější, z čeho se naše životy skládají, a dát čtenáři prostor se nad základy zastavit a přemýšlet o nich. Jsem však literární historička, ne teoretička - a tedy i můj badatelský přístup, zvláště k pohádce, byl povýtce literárněhistorický. V současnosti se chystám poněkud obrátit list a podívat se přesněji, jaký vliv měla na českou literaturu pro děti a mládež společenská, kulturní a politická situace v padesátých a šedesátých letech dvacátého století. Vracím se tím v podstatě ke svým počátkům (moje diplomová práce se zabývala následky roku 1948 pro českou dětskou literaturu). Uvidím, co se z toho nakonec vyklube...

Myslím, že výzkum v oblasti literatury pro děti a mládež měl od počátku náskok před ostatnimi oblastmi díky svému transdisciplinárnimu uchopováni predmětu svého bádání. Kam tento výzkum směřuje ve světové a kam v české literární vědě dnes?

Literatuře pro děti a mládež je překračování hranic mezi disciplinami vlastní - a domnívám se, že také v budoucnu, u nás i ve světě, bude. Patří to k jejím specifikům. Stačí začít od prostého recenzování: Jak hodnotit knížku pro děti, aniž bychom se zamysleli nad tím, budou-li jí v daném věku čtenáři rozumět, bude-li je bavit, dokonce je-li pro ně vhodná např. po etické stránce apod.? A už stojíme na hranicích s pedagogikou, psychologií a kdoví kde ještě. Podobné to je při veškerých úvahách o literatuře pro děti a mládež - třeba zamyšlení nad čtenářem ve vztahu $\mathrm{k}$ textu se při analýze nevyhneme prakticky nikdy.

Tato skutečnost se dá vzhledem $\mathrm{k}$ vývoji literární vědy považovat opravdu za náskok. Opět s sebou ovšem nese nejen výhody, ale rovněž rizika: dodnes se můžeme potkat $s$ tendencemi hodnotit literaturu pro děti více $z$ pohledů mimoliterárních (především didaktických) než literárních - uměleckých. Přílišná otevřenost na všechny strany může jít někdy na úkor hloubky literárního bádání. Za důležité proto považuji, aby literaturu pro děti „přijalo za svou“ co nejvíce literárních vědců - a naprosto nemusí jít pouze o to, aby si ji zvolili za hlavní oblast svého badatelského zájmu, jen o to, aby se jí nevyhýbali např. při kontextuálním uvažování, jak se dodneška zhusta děje. 
Kromě transdisciplinárního přístupu považuji za krok napřed také ochotu badatelů $\mathrm{z}$ oblasti literatury pro děti a mládež věnovat se seriózně žánrům „na okraji“, pokud jsou součástí živé četby. Pravděpodobně to souvisí mimo jiné s tím, že sama literatura pro děti a mládež se z okraje literatury vymanila teprve před pár desítkami let. U nás třeba patřili odborníci na literaturu pro děti k prvním, kdo se byli ochotni vážně zabývat žánrem fantasy. Zájmy nastupující badatelské generace, zdaleka nejen v oblasti literatury pro mládež, přitom dokazují, že chut vypořádat se na úrovni s díly a oblastmi tradičně řazenými do populární literatury, přehodnotit stávající soudy, je jednou z obecných vývojových tendencí literární vědy. A pokud je mi známo, neplatí to pouze u nás.

Jak se snoubí vlastní literárni tvorba s výzkumem? Inspiruje tě ve vědeckém přemýšlení o nějakých aspektech dětské literatury vlastní autorská zkušenost?

Osobní zkušenost s psaním beletrie považuji za výhodu především při prvotním uvažování nad textem a jeho rozkrýváním. Vnímám ji jako cestu navíc. Tu a tam je myslím snazší při autorském pohledu „zevnitř “ odhalit, co by jinak nemuselo být patrné, nebo ne snadno. Na druhé straně je podle mého soudu potřeba dávat si větší pozor na objektivitu hodnocení - stejně jako dobrý redaktor, který rovněž píše beletrii, nesmí při práci s textem vnucovat autorovi to, co by napsal on sám být na autorově místě.

Co může dát česká fantasy světu? Jaký je vztah dnešní české a zahraniční fantasy? Překládá se literatura pro dèti?

Dobrá česká fantasy by podle mého soudu mohla dát světu tolik, kolik může dát jakákoli dobrá kniha bez ohledu na žánr. Že by byla, jako celek, česká fantasy v současnosti něčím výjimečná (a tím přínosná pro světovou scénu), si nemyslím. Naopak velkou část dnešní české produkce chápu jako literární hledání, dokonce tápání - mnohde výrazně poznačené komercí - do značné míry závislé na zahraničních vzorech. To je snad odpověd' i na otázku po vztahu české a světové fantasy.

Připomenout je ovšem záhodno, že u nás vstoupil žánr na scénu minimálně o celou autorskou a čtenářskou generaci později než v západní Evropě a Spojených státech. Není proto divu, že máme stále co dohánět. A bojím se, že o nejlepších autorech ani nemusíme vědět. Mohli se nám ztratit v záplavě průměrného. 
Samozřejmě, existuje i tzv. slovanská fantasy, tedy fantasy opírající se o slovanskou mytologii, historii, pohled na svět, ke které bychom snad mohli (či měli?) něco dodat - ale pokud je mi známo, ani v této oblasti zdaleka nestojíme v čele, spíše velmi skromně a střídmě „klopýtáme“ především za polskou literaturou. Kromě toho podle mého soudu u fantasy nejde, nebo nemá jít o kulisy, byṫ by byly jakkoli neotřelé. To by byl totiž naprosto vnějškový přístup k věci.

Česká fantasy tedy bude mít co dát světové literatuře tehdy, najde-li osobité, jedinečné, kvalitní autory nepodléhající komerčním a dalším mimoliterárním diktátům a tlakům - a rovněž ( $\mathrm{a}$ to je zásadní podmínka) bude-li mít v zahraničí někdo vůbec zájem ji vydávat. Je známo, že o překlady z češtiny nyní valný zájem není. Zvláště velké knižní trhy (anglický, americký...) se o naši soudobou tvorbu mnoho nezajímají - a překládá-li se, překládají se hlavně „kritiky prověřená“, případně „cenami ověnčená“ díla/jména české literatury, ne ta stojící na okraji i v zemi svého vzniku. Nemám po ruce statistiku, vím však, že například literatuře pro děti musejí pomáhat za hranice (třeba i „jenom“ do Mad’arska) nekomerční projekty, vzniklé právě jako reakce na stávající neradostný stav. Ty jsou ovšem dosud v plenkách a jsou ojedinělé, musíme tedy počkat, zda se vỉbec uchytí.

Nechci být př́liš pesimistická, ale obávám se, že na naši fantasy - ani na naši dětskou knížku (která by si zatím pozornost zasloužila mnohem, mnohem víc!) - nikdo ve světě nečeká, natož aby ji vyhlížel - zvláště pominu-li nám tak přátelsky nakloněné Slovensko. I to, co bychom dát mohli, proto momentálně většinou není jak dávat.

Jaké autory máš ráda? Kteři Tě inspirují? Při čtení Tvého posledního románu jsem často myslela na Ursulu K. Le Guinovou - pro její i Tvůj cit pro jazyk, hudbu a poezii vyprávění -, ale i na Terryho Pratchetta - pro silné povědomí o moci a síle príběhu...

Bylo by pro mě snazší jmenovat knížky, které se do mě hlouběji otiskly, než autory - je velice málo těch, u nichž mě rovnocenně oslovilo celé jejich dílo. Zároveň mám pocit, že u každého jména nebo názvu by bylo potřeba dodat na vysvětlení proč, proč zrovna tento autor, zrovna tato kniha. A to by bylo na dlouho. Textů, jež se mě výrazně dotkly, byla řada, naprostá většina z nich přitom nespadá do fantasy. Na prvním místě mě vždycky napadne má velká láska z mládí, historické romány Henryka Sienkiewicze, s jejich smyslem pro postavu, prostředí a s jejich nesentimentální, přitom hlubokou emocionalitou, pak tu byla Tolstého Vojna a mír, Schulzův Kámen a bolest, Löwensköldův prsten Selmy Lager- 
löfové, spousta světové i české poezie - ale třeba i, o mnoho let později, Cesta Cormaca McCarthyho... Sluší se tu přiznat i k Tolkienovi.

Ale jak si tak vybavuji jednoho autora po druhém, už zase vidím, že konkrétními jmény a názvy odpověd’ spíš zamlžuji... Možná raději povím, jaké knihy ráda nemám: Nemám ráda texty vykonstruované na efekt jakéhokoli typu, autorsky neupřímné, a nemám ráda texty bez naděje (přičemž naděje - stejně jako třeba v Cestě - pro mě rozhodně neznamená totéž co prostý happy end).

Pokud jde o inspiraci, záleží na tom, co se za slovíčkem skrývá. Literárním vzorům se snažím důsledně vyhýbat. Prózu jsem začala psát poměrně pozdě, až na vysoké škole, vývojová fáze „chci psát jako..." mě i proto do značné míry minula. Učit se $z$ dobrých textů, jak se co dělá, je pro mě na druhou stranu př́irozené dodnes (a myslím, že to děláme všichni, často podvědomě). Což ovšem neznamená nějaké opisování. Mnohdy se (paradoxně?) naučím víc od autora, $\mathrm{s}$ nímž plně nesouzním, který mě nutí vést s ním tichý spor a tím si ujasňovat co a jak.

Dílo Ursuly K. Le Guinové mě v lecčem opravdu oslovuje, souhlasím s mnoha jejími názory na literaturu a roli autora ve společnosti (i já např. považuji poezii za neoddělitelnou součást literárního textu, zvláště textu se symbolickým přesahem, kam patří, může patřit, i fantasy) - a zároveň náleží Guinová $\mathrm{k}$ těm, kteří mě tu a tam provokují k vnitřním polemikám.

S Pratchettem jsem se dosud spíše míjela, ačkoli obdivuji jeho osobitost, inteligenci, nápaditost a jedinečný smysl pro humor (mnohokrát jsem se nad jeho knížkami skvěle pobavila). Možná mě toto setkání teprve čeká?

Shodujeme se v tom, že fantasy, už díky svému propojení s mýtem, je žánr s ohromným potenciálem. Př́liš často ale v knihkupectvích vidíme konvenční, nedomyšlené, a v důsledku nudné texty. Co je podle tebe hlavní príčina tohoto stavu?

Sama za sebe vidím tři hlavní přičiny:

1) Komerční tlaky - žánr je vzhledem k široké čtenářské obci nakladatelsky nosný, což přitahuje ty, pro něž je co největší výdělek v ediční i autorské práci nejdůležitější - to podporuje nedodělky, nekvalitu, epigonství a schematismus;

2) převládající neochota prestižní literární kritiky se fantasy seriózně zabývat a pomoci tím její kultivaci (naprosto chápu, že přehrabovat se těmi nekonečnými haldami knih je nesmírně obtížné a vzhledem $\mathrm{k}$ převaze textů nevalné úrovně úmorné - možná by však pro začátek stačilo přestat vnímat cokoli s nálepkou fantasy jako nutně kvalitativně pochybné, což se u nás zhusta dosud děje); 
3) specifické nastavení české komunity čtenářru fantasy (komunity nejednou velmi uzavřené a konzervativní), podporované specializovanými časopisy a samozřejmě internetem, komunity, která do značné míry předem očekává, že „správná“ fantasy bude mít ty a ty (a pouze ty a ty) atributy - a texty vybočující $z$ poměrně pevně daného, svazujícího schématu není vždy připravena přijímat.

Věřím, že přinejmenším v druhých dvou bodech se blýská na lepší časy - v západní Evropě a Spojených státech rozhodně.

Jiří Kratochvil říká, že poctivý autor se musí svým románem probolet. Rozumím tomu tak, že prožívá s postavami dobré i zlé. Při četbě Tvého posledního románu Bílí havrani jsem na to musel myslet $v$ epizodě, kdy kněžna nabídne svůj život za záchranu krále, kterého miluje. Zpočátku to vypadá jako nadsázka, jako tradiční schéma velkého slibu, který nakonec nebude vyžadován - ovšem až do chvíle, kdy odvážná kněžna předstoupi před strašného zachránce; najednou vidíme, že to nejsou slova, ale čin, který se zhmotní: vždyt'on si opravdu vezme její život, a ona to ví. - Prozradiš mi, prosím, jak vznikají takové texty? Kolik musí autor obětovat ze své duše, aby byl takový príběh uvěřitelný, umělecky pravdivý?

Své texty, přinejmenším ty poslední, opírám skutečně o postavy. Vždycky mi poté udělá velkou radost, osloví-li čtenáře a zdají se jim uvěřitelné. Kéž by mé postavy nikdy „nešustily papírem“! - Ale dobře vím, že ne všechno se podařilo a i v budoucnu se jistě spousta nepodaří.

Patřím k autorům, kteří musejí své postavy dobře znát. Potřebuji, aby přinejmenším hlavní z nich, „začaly žít vlastním životem“ - tedy se mi svým způsobem vymkly a „dělaly si věci po svém“. Přirozeně to míním s nadsázkou, autor je autor, postava zůstává postavou - nepromění se v živého člověka. A přece občas (a já to považuji za štastnou chvíli) se stane, že si jako autorka něco naplánuji - a najednou vidím, tváří v tvář konkrétní postavě a scéně, že postava něco, co jsem jí chtěla nadiktovat, zkrátka neudělá - respektive udělá jedině za cenu toho, že bych ji zlomila, a tím znedůvěryhodnila.

Tento přistup k psaní, jsem si jistá, je pouze jedním z mnoha. Není spolehlivější nebo bezpečnější, co se kvality výsledku týče. Je značně subjektivní, ve své podstatě romantický - ale já jinak psát zatím neumím.

Začínám jako u kreslení obrázku: téma, resp. témata, náčrt děje, základní obrysy - a pak přidávat detail za detailem, mnohdy droboučké a zdánlivě nepodstatné (kolik však změní při kresbě nebo malbě dotek bílou barvou na černé zorničce oka!), dlouho ladím, opakovaně se k textu vracím. Psaní má oproti kresbě 
výhodu: pokazím-li tah tuší na papír, zbývá obrázek pouze roztrhat - v knížce mohu zpětně škrtat a měnit beze stop na výsledném tvaru. Každopádně píšu pomalu, postavy dlouho nosím všude s sebou - a čekám, až je já sama poznám a pochopím. Pokud se to nestane, nedá se nic dělat - takový text nedokážu dopsat, podobně jako pokažený obrázek si zaslouží jen a jenom vyhodit.

Psaní samo mě baví. Stojí sice hodně sil, čas, který by člověk mohl využít jinak - zároveň mi však dává prostor k přemýšlení o tom, co mi leží v hlavě, a já si tedy přemýšlím se svými postavami, které jsou zpravidla hodně jiné než já sama (což je u přemýšlení výhoda), získávám odstup a ledacos se dozvím nejen o nich. Svým způsobem tak u psaní většinou odpočívám.

Když člověk v roli autora nebo učitele vydává - a to musí - kde se nabijí? Kde čerpáš inspiraci, radost, jak přkenonáváš negativni síly? Naučil Tě to někdo? Nebo hraje roli genetika? Našla jsi vlastní recept proti stresu, temným silám, únavě? Nedokážu si jinak vysvětlit, jak to všechno stíháš.

Nemyslím si, že jsem člověk, který dobře stíhá, naopak! Jsem přesvědčená, že jiní na mém místě by zvládli mnohem víc. Nejde mi přiliš dělat dvě věci naráz, přebíhat od jedné $\mathrm{k}$ druhé. Aby se všechno vešlo do jednoho dne, snažím se na to, čím se právě zabývám, maximálně soustředit (mnohdy to pochopitelně nejde), neztrácet čas zbytečným přerušováním, opakovaným, celodenním otevíráním mailů apod. A psaní beletrie, zabírající v mém současném životě pouze pozici koníčku, mnohdy týdny, dokonce měsíce musí čekat, až na ně „bude kdy“.

Odpočívám $\mathrm{v}$ přírodě (bez Vysočiny skomírám...), u dobré muziky různých žánrů, důsledně se snažím udělat si čas na lidi okolo, na přátele. Nutně potřebuji tu a tam naprosto „vypnout“, zapomenout na práci a povinnosti, vytěsnit je, udělat si program jen a jen pro radost (a třeba jeho přípravě věnovat i kus úsilí).

Učila jsem se podobně jako ostatní, od rodičů, širší rodiny, přátel... A v tomto směru mám odjakživa mimořádné štěstí.

A pokud jde o ty „temné síly“, pocity bezvýchodnosti, života postrádajícího smysl - opírám se o přesvědčení, že na nic v našem bláznivém rozvráceném světě, uvěznění v historii plné nepochopitelné krutosti i v šedivé, ubíjející všednodennosti, do níž se nám občas ani nechce probouzet, nejsme my lidé sami.

Děkujeme za rozhovor a přejeme hodně dobrých, tvůčích sil. 
